\title{
Xenia negatively affecting kopyor nut yield in Kalianda Tall kopyor and Pati Dwarf kopyor coconuts
}

\author{
Maskromo Ismail1,2, Larekeng Siti Halimah ${ }^{1,3}$, Novarianto Hengky², Sudarsono Sudarsono ${ }^{1 *}$ \\ ${ }^{1}$ PMB Lab., Department of Agronomy and Horticulture, Faculty of Agriculture, IPB, Bogor 16680, Indonesia, ${ }^{2}$ Indonesian Palm Research \\ Institute, Agency for Agricultural Research and Development (AARD), Manado, Indonesia, ${ }^{3}$ Department of Sylviculture, Faculty of Forestry, \\ Hasanuddin University, Makasar, Indonesia
}

\section{A B S T R A C T}

\begin{abstract}
Xenia is a phenomenon usually associated with phenotype characters controlled by a single recessive gene. The genotype of pollen donor directly determines the phenotype of fruits or seeds harvested from female recipients. Kopyor coconut is a unique coconut mutant and its formation is an example of xenia, since the genotype of the pollen donor determines the phenotype of the harvested nuts. The objectives of this research were to evaluate xenia in two types of kopyor coconuts (i.e. Kalianda Kopyor Tall and Pati Kopyor Dwarf), determine effects of homozygous KK normal and heterozygous Kk Kopyor coconut ratio, and effects of homozygous KK normal coconuts removal from mix population on yield of Kopyor nuts. For Kalianda Tall Kopyor coconut, field observations were conducted at three kopyor coconut plantations in Kalianda district, Lampung Selatan, Lampung-Indonesia while observations of Pati Dwarf Kopyor were conducted at Tayu district, Pati, Central Java-Indonesia. In both regions, coconut provenances were mapped using GPS and sub-samples were taken based on determined criteria. For each sampled tree, observations were recorded for the following variables: nut yield and yield components. The quantitative data were subjected to t-test statistical analysis to evaluate the significant differences among the observed parameters. Results of this experiment showed the presence of more homozygous KK normal coconuts among provenances of Kalianda Tall heterozygous Kk Kopyor coconut resulted in lower harvested kopyor nuts than the expected value. Moreover, removal of homozygous KK normal coconuts from a mixed coconut population increased yield of kopyor nuts. Those results indicated xenia occurred in both Kalianda Tall and Pati Dwarf Kopyor coconuts and it negatively affected the kopyor nut yield.
\end{abstract}

Keywords: Coconut mutant; Endosperm abnormality; Kopyor endosperm; Pollen donor; Recessive gene

\section{INTRODUCTION}

A number of coconut mutants having abnormal endosperm phenotype have been reported under locally different names, such as Makapuno in the Philippines, Maphrao Kathi in Thailand, Dikiripol in Sri Lanka, Thairu Tengai in India, Dua Sap in Vietnam, and Dong Kathi in Cambodia (Novarianto et al., 2014). Kopyor coconut is one of the many exotic coconut types existing in Indonesia (Maskromo et al., 2007; Sudarsono et al., 2013). It has a high economic value in Indonesia since the demands are high whereas the supplies are limited. The price of kopyor coconut in Indonesian markets can be up to 10 times more expensive than the normal coconut (Novarianto and Lolong, 2012; Larekeng et al., 2015). The unique characters of kopyor coconut include an abnormal, soft and fluffy endosperm. The abnormal endosperm texture is like tender coconut even though the nuts are harvested at 10-11 months after pollination (MAP). Moreover, the endosperm is also peeled off from the endocarp (Maskromo et al., 2014). Normal coconut, on the other hand, has a hard endosperm when harvested at 10-11 MAP (Maskromo et al., 2013). The commercial uses of the kopyor coconut endosperm include: fresh consumption and as additive material for ice cream product (Maskromo et al., 2015).

A single recessive mutant $\mathrm{k}$ allele in a $\mathrm{K}$ locus probably controls kopyor mutant phenotype in coconut (Sukendah et al., 2009). Based on the phenotype and the genotype of endosperm and zygotic embryo, there are three classes of coconuts: (1) kopyor - mutant homozygous kk nuts, (2) Normal - wild type homozygous KK nuts, and (3) Normal - heterozygous Kk nuts (Sudarsono et al., 2013). The phenotype of a kopyor endosperm is abnormal 
and the genotype is a homozygous kkk; the phenotype of a wild type normal endosperm is hard and the genotype is a homozygous KKK, while the phenotype of normal heterozygous Kk type endosperm is the same as wild type but the endosperm is either heterozygous KKk or Kkk. In nature, the kopyor mutant allele is preserved in the form of normal heterozygous Kk nuts (Sudarsono et al., 2013) and Kopyor nuts can only be generated by fertilization of a $\mathrm{k}$ female gamete by a $\mathrm{k}$ male. On the other hand, fertilization of a k female gamete by a $\mathrm{K}$ male immediately results in coconut having normal endosperm phenotype. Therefore, the genotype of the male gametes (pollens) determine the phenotype of the harvested nuts to either be kopyor or normal types (Sudarsono et al., 2013).

Kopyor coconut plantations have been established in Pati, Central Java; Sumenep and Jember, East Java; Tangerang, Banten, West Java, and Kalianda, South Lampung (Maskromo et al., 2011). The genotypes of kopyor coconuts in those regions were heterozygous Kk. The heterozygous Kk Kopyor were interspersed with the homozygous KK normal coconuts. Therefore, the Kalianda Tall coconut population usually consisted of a mixture of both the genotypically heterozygous Kk kopyor and the homozygous KK normal coconuts (Sudarsono et al., 2013) and they were surrounded by the normal coconut trees for copra production (Disbun Lampung Selatan, 2011). The Dwarf Kopyor coconut plantation in Pati, Central Java also exists as mixtures of Dwarf, Tall, and Hybrid Kopyor, Normal Dwarf and Tall coconuts, respectively (Dishutbun Pati, 2004). Typical yield of kopyor nuts harvested from Kalianda Tall Kopyor coconut in Kalianda, South Lampung is only 1-2 kopyor nuts out of 7-10 total nuts/bunch. On the other hand, Pati Dwarf Kopyor coconut yield 1-4 kopyor nuts out of 7-15 total nuts/bunch. Based on the Mendel segregation law, the chance of a kopyor nut formation should be about $25 \%$ of the total number of harvested nuts (Maskromo, 2007). Xenia may have affected kopyor nut yield in a mixture of Kopyor and normal coconut plantation (Sudarsono et al., 2015).

According to Olfati et al. (2010), xenia is the phenomenon of male parental genotype effects through produced pollen on the development of fruit and seeds from the female parents. Xenia has been evaluated in dates (Faraq et al., 2012), maize (Viorica and Dorina, 2013) and coconut. Xenia in coconut results in increasing the nut size, copra weight and hybrid vigor (Satyabalan, 1995). The formation of kopyor phenotype in coconut is determined by the male parental genotype. Female parent carrying a $\mathrm{k}$ allele can only produce kopyor if it is fertilized by male gamete carrying the $\mathrm{k}$ allele. If the male gamete carries the $\mathrm{K}$ allele, it will yield a normal nut. The formation of kopyor nut requires the fertilization of both the $\mathrm{k}$ allele from female and male parents and is determined by the genotype of the pollen donor (xenia).

Pollination of the female flowers of a heterozygous $\mathrm{Kk}$ Kopyor coconut by pollen originating from a homozygous KK normal male parent is predicted to yield $100 \%$ normal nuts (Sukendah et al., 2009; Sudarsono et al., 2015). This indicates that the presence of homozygous $\mathrm{KK}$ normal coconuts surrounding the heterozygous $\mathrm{Kk}$ kopyor could affect the kopyor nut yield. However, no documented quantitative data have been published on this. The objectives of this research were to (1) evaluate xenia in two types of Kopyor coconuts, such as Kalianda Tall Kopyor and Pati Dwarf Kopyor coconuts, (2) quantify negative effects of homozygous KK normal coconuts on kopyor nut yield of the Kalianda Tall Kopyor, and (3) determine positive effects of homozygous KK normal coconut removal (thinning) on kopyor nut yield of Pati Dwarf Kopyor coconuts.

\section{MATERIALS AND METHODS}

\section{Research sites}

The field observations were conducted at two research regions, Kalianda, South Lampung and Pati, Central Java, Indonesia, from May 2011 to May 2014. Three Kalianda kopyor Tall coconut plantations at Agom Jaya (GPS position: S 539.478 E 105 34.978), Palembapang (GPS position: S 543.938 E 105 38.698) and Kecapi (GPS position: S 541.803 E 105 38.671) villages, Kalianda and one Pati Dwarf Kopyor coconut plantation at Sambiroto (GPS position: S 632.182 E 111 03.354) village, Pati were selected.

\section{Xenia in Kalianda Tall Kopyor coconuts}

The evaluated coconut plantations consisted of a mixture of Kalianda Tall heterozygous Kk Kopyor and Kalianda Tall homozygous KK normal coconut provenances. The ages of evaluated coconuts were approximately 20-25 years. Prior to evaluation, existing adult trees in the selected locations were numbered and their positions mapped using GPS. The identity of Kalianda Tall heterozygous Kk Kopyor coconuts in the research sites were determined based on the owner's information and verified by harvesting kopyor nuts from each tree by local kopyor nut harvesters. The ratio of heterozygous Kk Kopyor and homozygous KK normal trees were determined for each research site.

In all locations, number of bunches per plant for each of heterozygous $\mathrm{Kk}$ kopyor coconut were recorded for three consecutive years (2011-2013). Three successive bunches were sampled from each heterozygous Kk kopyor coconut every year and the number of total nuts and kopyor nuts 
per bunch were recorded. Kopyor nuts were harvested at 10-11 months after anthesis during the three year periods. Identity of the kopyor phenotype was confirmed by splitting the nuts and observing the abnormal endosperm. Yearly total nut and kopyor nut yield were calculated based on the total number of bunches per plant, average number of total nuts and kopyor nuts per bunch. Since formation of coconut inflorescences was associated with amount of rainfall in the two years prior to harvesting, the amount of rainfalls during the period of 2009-2011 were collected from the local climate station. The quantitative data was statistically analyzed using Minitab Statistical software package version 16.0.

To further investigate effect of ratio between homozygous $\mathrm{KK}$ normal and heterozygous Kk Kopyor coconuts on kopyor nut yield of the Kalianda Tall Kopyor, two subsamples with different ratio between $\mathrm{KK}$ and $\mathrm{Kk}$ (KK: $\mathrm{Kk}$ ) were drawn from the mix population of. Kalianda Tall Kopyor coconuts. The sub-sample, consisted of a small plot approximately $1000 \mathrm{~m}^{2}$ and containing a total of 12-18 coconuts, was identified using purposive random sampling approach. Ratio between KK: Kk coconut in the first sub-sample (Sub-sample 1) was 2: 1, in which six heterozygous $\mathrm{Kk}$ kopyor coconuts were surrounded by $10-12$ homozygous KK normal coconuts). In the second sub-sample (Sub-sample 2), the ratio between $\mathrm{KK}: \mathrm{Kk}$ coconuts was 1: 1, in which 6-7 heterozygous Kk kopyor coconuts were surrounded by six homozygous KK normal coconuts. Three replicates were selected from each research site at Kalianda, South Lampung. The number of bunches per tree, the number of total nuts and kopyor nuts per bunch were recorded while the yearly total nut and kopyor nut yield was estimated as previously described.

Molecular Analysis of Xenia in Kalianda Tall coconuts To proof the homozygous KK normal coconuts did contribute $\mathrm{K}$ allele carrying pollen and caused xenia in Kalianda Tall Kopyor coconuts, three homozygous Kk kopyor coconut trees were selected as female parents and their progeny were harvested for further evaluation. The harvested nuts (10 nuts/female parent) were germinated and three seedlings were randomly sampled from each female parent. The genotype identities of the female parents, the progeny arrays, and a number of potential male parents surrounding the selected female parents were determined using SSR and SNAP markers following procedures previously applied to.coconuts (Larekeng et al., 2015). Parentage analysis using the genotype of progeny, female parents, and potential male parents was done using CERVUS version 2.0 software (Marshall et al., 1998). Identification of the candidate male parents was done by analyzing genotype of progeny arrays and the respective female parents versus the genotypes of all adult trees surrounding the females. The identity of the potential male parent for any progeny was determined using the results of parentage analysis. Simulation was conducted to determine the threshold level for confidence interval of $80 \%$ (relax) and $95 \%$ (strict) levels before the final parentage analysis steps. Most likely approach (potential male parent with the highest LOD score) based on the matching genotype of progeny, female parent and potential male parent were used as the basis for assigning certain coconut provenance as the potential male parent or pollen donor of a progeny. The frequency of identified homozygous KK normal or heterozygous Kk kopyor male parents were counted to support the presence of xenia among Kalianda Tall Kopyor coconuts.

\section{Xenia in Pati Dwarf Kopyor coconuts}

The evaluated coconut provenances consisted of a mixture of Dwarf, Tall, and Hybrid Kopyor; Dwarf and Tall normal coconuts, respectively. The ages of the evaluated provenances were approximately 15-20 years. Prior to evaluation, all of the existing coconut provenances in the Pati research site were numbered and their position mapped using GPS. The identity of Pati Dwarf heterozygous $\mathrm{Kk}$ kopyor coconuts was determined based on owner's information and verified by harvesting kopyor nuts from each tree by local harvesters. The initial numbers of homozygous KK normal coconuts in the research site was determined in 2011. Three sub-samples, each consisting of a small plot of approximately $625 \mathrm{~m}^{2}$ for each sub-sample, were selected using purposive random sampling approach. Each sub-sample contained a mixture of 16-25 heterozygous Kk kopyor and homozygous KK normal trees. In 2011, three successive bunches were sampled from each of the heterozygous Kk kopyor coconut in the selected sub-samples and the number of total nuts and kopyor nuts per bunch were recorded. Percentages of kopyor nuts per bunch were calculated based on the ratio of kopyor to the total nuts. The nuts were harvested at 10-11 months after anthesis and identity of the kopyor phenotype was confirmed by splitting the harvested nuts and observing the abnormal endosperm.

To investigate the positive effect of the removal of homozygous $\mathrm{KK}$ normal coconuts on kopyor nut yield of Pati Kopyor provenances, the homozygous KK normal coconuts were gradually cut down from the research site in 2012 and 2013. In 2014, yield of the sub-sampled plots after removal of homozygous KK normal coconut were recorded again. Three successive bunches were sampled from each of heterozygous $\mathrm{Kk}$ kopyor coconut in the selected sub-samples and number of total nuts and kopyor nuts per bunch were recorded. Percentages of kopyor nuts per bunch were calculated as previously described. Yield of heterozygous Kk Kopyor coconut after removal of 
the homozygous KK normal coconuts (2014 data) were compared to those before removal (2011 data). The data was statistically analyzed using Minitab Statistical software package version 16.0.

\section{RESULTS AND DISCUSSION}

\section{Xenia in Kalianda Tall Kopyor coconuts}

Kopyor is an abnormal coconut endosperm phenotype found in various places in Indonesia and it differs to that of Makapuno type mutant found in other countries and to that of normal coconut (Fig. 1a-c). The normal endosperm is controlled by a dominant $\mathrm{K}$ allele while the kopyor phenotype is associated with a recessive $\mathrm{k}$ mutant allele in the $\mathrm{K}$ locus of coconut genomes (Sudarsono et al., 2015; Sukendah et al., 2009). Genotype of the coconuts naturally bearing kopyor nuts are heterozygous Kk (Novarianto et al., 2014).

In a double fertilization model, one male sperm nucleus fertilizes the female gamete and result in a diploid zygote while the second sperm nucleus fuses with two polar nuclei resulting in the triploid endosperm tissues (Steward-Cox et al., 2004). The predicted genotype and phenotype segregation among progeny derived from hybridization between two heterozygous $\mathrm{Kk}$ Kopyor or between heterozygous $\mathrm{Kk}$ Kopyor and homozygous KK normal parents are presented in Table 1. The expected genotype of a zygotic embryo isolated from kopyor nut should be a homozygous kk and the endosperm be a homozygous kkk (Table 1). Therefore, the expected kopyor nut yield from hybridizations between two heterozygous Kk Kopyor coconuts is $25 \%$ of the total harvested nuts, whereas no kopyor nut is expected from hybridization between the heterozygous Kk Kopyor and the homozygous KK normal parents (Table 1).

The GPS maps of the Kalianda Tall coconut provenances at the three research sites in Kalianda, South Lampung

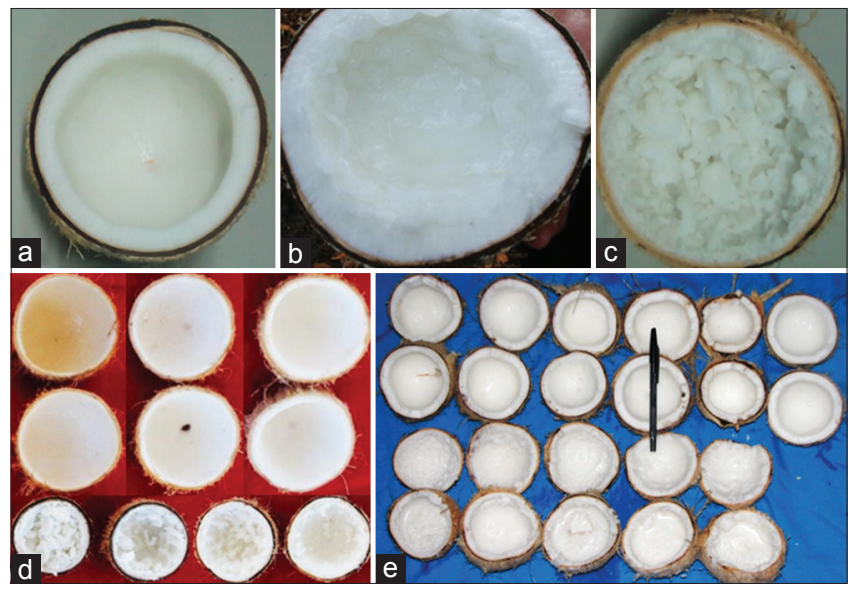

Fig 1. The phenotype differences of coconut endosperm (a-c): (a) Normal, (b) Makapuno and (c) Kopyor coconut endosperms. (d) Segregation of endosperm phenotype in a bunch of Kalianda Tall Kopyor coconuts, out of 5 nuts per bunch -2 are kopyor and 3 are normal nuts. (e) Segregation of endosperm phenotype in a bunch of Pati Dwarf Kopyor coconuts, out of 11 nuts per bunch - 5 are kopyor and 6 are normal nuts.

Table 1: Segregation model for progeny derived from hybridization between two heterozygous Kk kopyor coconuts, between heterozygous Kk kopyor and homozygous KK normal, and between heterozygous Kk kopyor and homozygous kk Kopyor coconuts

\begin{tabular}{|c|c|c|}
\hline Male gemetes & K & $\mathbf{k}$ \\
\hline \multirow[t]{2}{*}{ Female gamete } & \multicolumn{2}{|c|}{ (a) Hybridization between heterozygous Kk kopyor and heterozygous Kk kopyor } \\
\hline & \multicolumn{2}{|c|}{ Genotype (phenotype) of zygotic embryos: } \\
\hline K & KK (normal homozygous) & Kk (normal heterozygous) \\
\hline \multirow[t]{2}{*}{ k } & Kk (normal heterozygous) & kk (Kopyor homozygous) \\
\hline & \multicolumn{2}{|c|}{ Genotype (phenotype) of endosperm: } \\
\hline KK & KKK (normal endosperm) & KKk (normal endosperm) \\
\hline kk & Kkk (normal endosperm) & kkk (Kopyor endosperm) \\
\hline \multirow[t]{2}{*}{ Female gamete } & \multicolumn{2}{|c|}{ (b) Hybridization between heterozygous Kk kopyor and homozygous KK normal } \\
\hline & \multicolumn{2}{|c|}{ Genotype (phenotype) of zygotic embryos } \\
\hline K & KK (normal homozygous) & NA \\
\hline \multirow[t]{2}{*}{ k } & Kk (normal heterozygous) & NA \\
\hline & \multicolumn{2}{|c|}{ Genotype (phenotype) of endosperm } \\
\hline KK & KKK (normal) & NA \\
\hline kk & Kkk (normal) & NA \\
\hline \multirow[t]{2}{*}{ Female gamete } & \multicolumn{2}{|c|}{ (c) Hybridization between heterozygous Kk kopyor and homozygous kk Kopyor } \\
\hline & \multicolumn{2}{|c|}{ Genotype (phenotype) of zygotic embryos } \\
\hline K & NA & $\mathrm{Kk}$ \\
\hline \multirow[t]{2}{*}{$\mathrm{k}$} & NA & $\mathrm{kk}$ \\
\hline & \multicolumn{2}{|c|}{ Genotype (phenotype) of endosperm } \\
\hline KK & NA & KKk (normal endosperm) \\
\hline kk & NA & kkk (Kopyor endosperm) \\
\hline
\end{tabular}

The KK or Kk are genotype of zygotic embryos with normal endosperm and kk is that with kopyor endosperm phenotypes. The KKK, KKk or Kkk are the genotype of endosperm tissues with normal endosperm and kkk is that with kopyor endosperm phenotypes. (NA) the genotype and phenotype are not available among progenies 
are presented in Fig. 2. There are 134 heterozygous Kk kopyor coconuts interspersed in a total of 282 trees at Agom Jaya (Fig. 2a). The ratio between homozygous KK normal and heterozygous Kk Kopyor at this 2 ha Agom Jaya site is 1.1: 1. At the 1 ha Palembapang research site, there are 69 heterozygous $\mathrm{Kk}$ kopyor in a total of 134 trees (Fig. 2b) with the ratio between homozygous KK and heterozygous $\mathrm{Kk}$ is $0.9: 1$. At the 5 ha Kecapi site, there are 116 heterozygous $\mathrm{Kk}$ kopyor interspersed in a total of 515 trees (Fig. 2c) with the ratio between homozygous KK and heterozygous $\mathrm{Kk}$ is 3.4:1. The annual total nut yield/ tree of Kalianda Tall Kopyor coconut during three years of observation (2011-2013) is not significantly different (Fig. 3). The total nut yield at Agom Jaya ranges from 39.2 to 77.8; at Kecapi 36.9 to 75.7; and at Palembapang from 39.3 to 70.0 nuts/tree/year (Fig. 3), whereas the kopyor nut yield at Agom Jaya research site ranges from 5.7 to 10.3; at Kecapi 3.1 to 9.6; and at Palembapang 6.6 to 15.4 nuts/tree/year (Fig. 4). The amount of yearly rainfalls two years before harvesting at Kalianda (Figs. 3 and 4) were 160.3 in 2009, 205.0 in 2010, and $119.7 \mathrm{~mm} /$ year in 2011. The total nuts and kopyor nut yield is probably associated with the amount of rainfalls during the two years prior to harvesting of the nuts. The calculated percentages of kopyor nut yield in all three locations ranges from $8.5 \%$ to $22.2 \%$ and they are less than the expected value of $25 \%$. The low percentages of kopyor nut yield may be because of the negative effects of xenia since the presence of more homozygous KK normal coconuts result in more contribution of $\mathrm{K}$ allele carrying pollen, forming more nuts with either homozygous KK or heterozygous Kk zygotic embryos, both having a normal endosperm phenotype (Table 1). The examples of endosperm phenotype segregation (normal versus kopyor endosperm) from a single bunch of Kalianda Tall heterozygous Kk kopyor coconut is presented in Fig. 1d.

To further investigate negative effect of xenia on kopyor nut yield, two sub-samples with different ratios of homozygous KK normal and heterozygous Kk kopyor coconuts (Fig. 2) were drawn from the three research sites. The average number of harvested nuts/bunch is not significantly different between the sub-sample 1 and sub-sample 2, whereas the number of total nuts/tree/year in sub-sample 2 is significantly higher than that of sub-sample 1 in Kecapi and Agom Jaya (Table 2). Both average number of kopyor nuts/bunch and kopyor nuts/tree/year in sub-sample 2 are significantly higher than those of sub-sample 1 in all three locations (Table 2). In all three locations, the percentage of kopyor nuts/bunch is also slightly higher in the sub-sample 2 than that of sub-sample 1 (Fig. 5). In both sub-sample 1 and 2, however, the percentage of kopyor nuts/bunch is less than the expected, which base on single locus Mendelian segregation is $25 \%$. The percentage

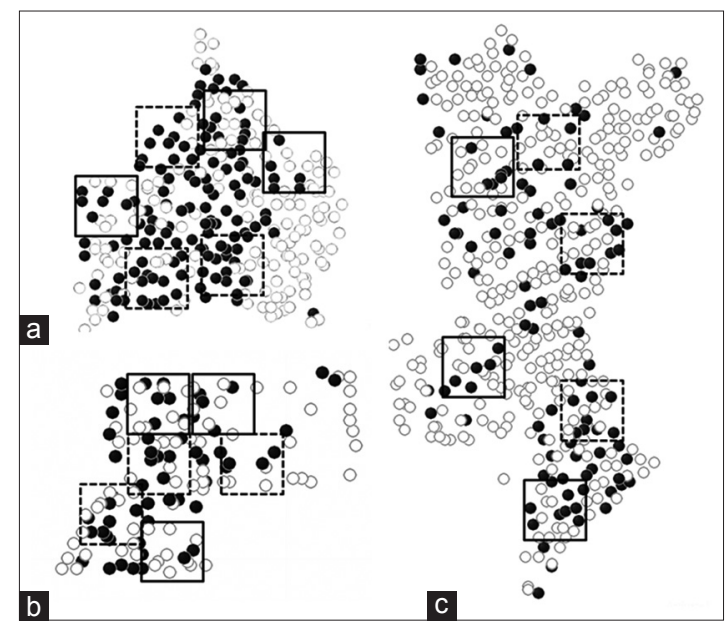

Fig 2. Maps of the coconut provenances of Kalianda Tall Kopyor coconut populations in three research sites: (a) Agom Jaya, (b) Palembapang, and (c) Kecapi, South Lampung, Lampung, Indonesia. Small plots indicate the evaluated sub-samples. Sub-sample 1: the ratio between homozygous KK normal and heterozygous Kk Kopyor coconut provenances is 2:1. Sub-sample 2: the ratio between homozygous KK normal and heterozygous Kk Kopyor coconut provenances is 1:1.

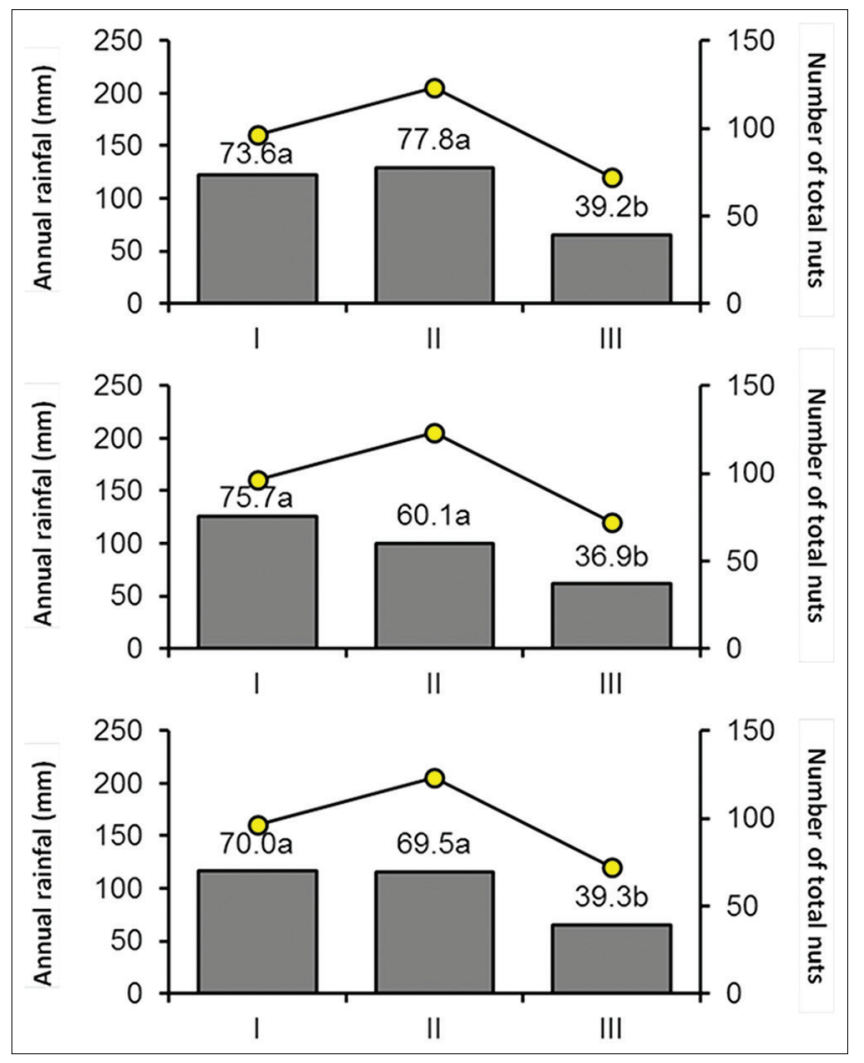

Fig 3. Association between amount of annual rainfal and total nut yield/tree/year at three locations: Top: Agom Jaya, Middle: Kecapi, and Bottom: Palembapang, South Lampung, Lampung, Indonesia. Annual rainfal was recorded at I: 2009, II: 2010, and III: 2011 (two years before yield observation) whereas numbers of total nuts/tree/year were recorded at I: 2011, II: 2012, and II: 2013. For each location, numbers followed by the same letter indicated not significantly different based on T-test at $\alpha=0.05$ level. 
of kopyor nut/bunch in sub-sample 1 ranging from $9.1 \%$ to $10.8 \%$ and in sub-sample 2 from $12.5 \%$ to $17.1 \%$ (Fig. 5).

Molecular Analysis of Xenia in Kalianda Tall coconuts Pollen contribution from homozygous KK normal coconuts caused xenia in Kalianda Tall Kopyor coconuts. To evaluate the presence of pollen contribution from normal coconuts, three homozygous $\mathrm{Kk}$ kopyor coconuts were

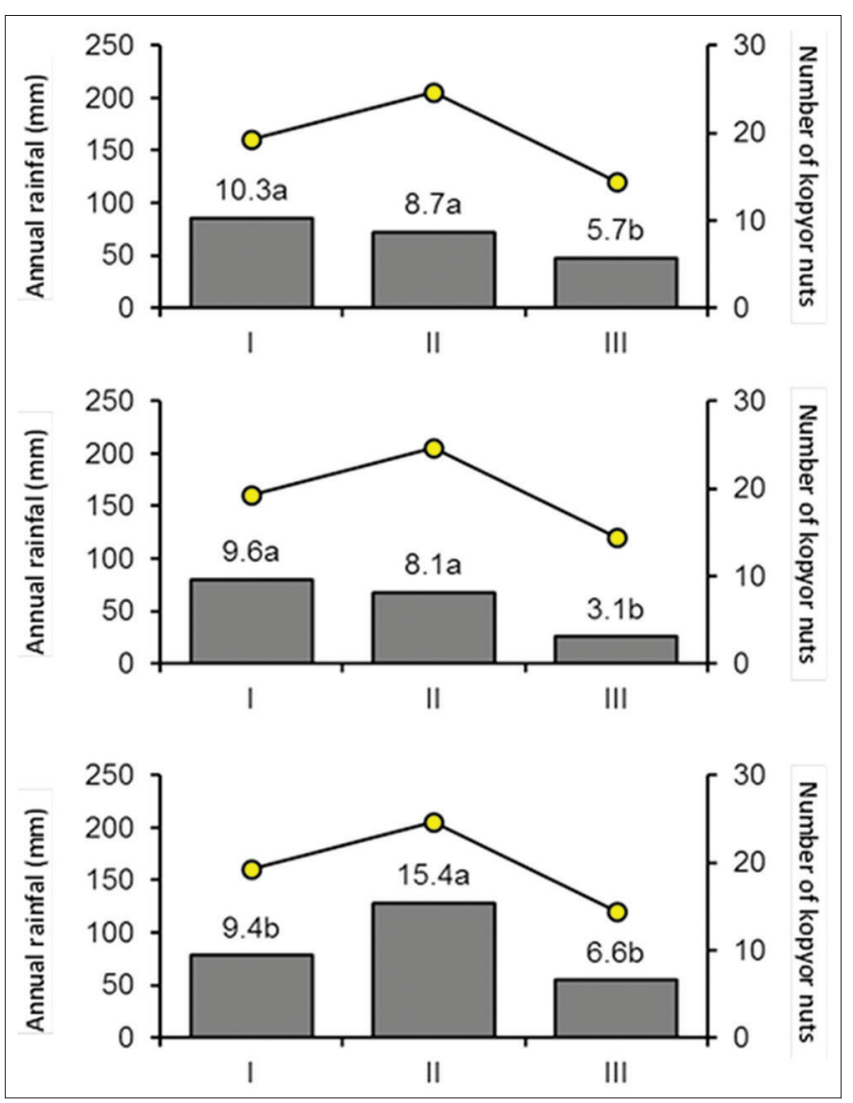

Fig 4. Association between amount of annual rainfal and total kopyor nut yield/tree/year at three locations, Top: Agom Jaya, Middle: Kecapi, and Bottom: Palembapang, South Lampung, Lampung, Indonesia. Annual rainfal was recorded at I: 2009, II: 2010, and III: 2011 (two years before yield observation) whereas numbers of kopyor nuts/tree/ year were recorded at I: 2011, II: 2012, and II: 2013. For each location, numbers followed by the same letter indicated not significantly different based on T-test at $\alpha=0.05$ level. selected as female parents and their progeny were evaluated. The identity of the male parents contributing pollen in each of the progeny were assigned base on parentage analysis. Results of the analysis indicate a fraction of progeny harvested from the three female heterozygous $\mathrm{Kk}$ parents are the results of hybridization with homozygous $\mathrm{KK}$ normal coconut male parents. The frequency of pollen contributed by the homozygous KK normal male parents to the heterozygous $\mathrm{Kk}$ kopyor female parents is presented in Table 3. The identified male homozygous KK normal coconuts contribute up to two pollen, causing formation of normal nuts from heterozygous $\mathrm{Kk}$ female parent no. 149, 156, and 163 (Table 3). Representative positions of the heterozygous $\mathrm{Kk}$ female parent no. 156 and the male parent of either heterozygous $\mathrm{Kk}$ or homozygous $\mathrm{KK}$ donating pollen in the evaluated progeny are presented in Fig. 6. Results of molecular analysis in the mix population of Kalianda Tall coconut demonstrate pollen contribution from homozygous $\mathrm{KK}$ normal male parent to the heterozygous $\mathrm{Kk}$ females in the harvested coconuts. Since pollination by the $\mathrm{K}$ allele carrying pollen result in formation of normal nut, the presence of the homozygous $\mathrm{KK}$ normal coconuts would reduce the chance for kopyor nut yield from heterozygous $\mathrm{Kk}$ female parents.

\section{Xenia in Pati Dwarf Kopyor coconuts}

The majority of Dwarf Kopyor coconuts exist in Pati, Central Java, Indonesia. The Pati Dwarf Kopyor coconut plantation with more than 150 coconut provenances in one area has been identified and used in this experiment. Mapping of coconut provenances at Sambiroto village, Tayu district, Pati, Central Java indicated the presence of a mix cropping among homozygous KK normal and heterozygous Kk kopyor coconut provenances (Fig. 7). Total number of coconut provenances prior to removal of the homozygous $\mathrm{KK}$ were 158 trees, consisting of 40 homozygous $\mathrm{KK}$ normal and 118 heterozygous $\mathrm{Kk}$ kopyor coconuts (Fig. 7a.) and the ratio between $\mathrm{KK}$ : Kk was 1:2.95. The homozygous $\mathrm{KK}$ normal coconuts were selectively cut down in 2012 and 2013, leaving only 19 trees (Fig. 7b) and the ratio between KK: Kk changed into 1:6.21.

Table 2: Differences in average number of total nuts (NTN) and Kopyor nuts (NKN) per bunch, percentage of Kopyor nuts (\% KN) per bunch, number of total nuts and Kopyor nuts between two sub-sample plots of Kalianda Tall heterozygous Kk kopyor coconuts at three locations. Data were the average of three years of observation

\begin{tabular}{|c|c|c|c|c|c|c|}
\hline $\begin{array}{l}\text { Research } \\
\text { sites }\end{array}$ & Sub-sample & NTN/bunch (nuts) ${ }^{a}$ & NKN/bunch (nuts) & $\% \mathrm{KN} / \mathrm{bunch}$ & NTN/tree/year (nuts) & NKN/tree/year (nuts) \\
\hline \multirow[t]{2}{*}{ Kecapi } & 1 & $4.97 a$ & $0.52 b$ & 10.5 & $47.53 b$ & $4.87 b$ \\
\hline & 2 & $5.54 a$ & $0.67 a$ & 12.1 & $58.73 a$ & $7.09 \mathrm{a}$ \\
\hline \multirow[t]{2}{*}{ Agom Jaya } & 1 & $6.06 \mathrm{a}$ & $0.54 b$ & 8.9 & $65.80 a$ & $5.94 b$ \\
\hline & 2 & $6.51 \mathrm{a}$ & $0.89 a$ & 13.7 & $70.70 a$ & $9.59 a$ \\
\hline \multirow[t]{2}{*}{ Palembapang } & 1 & $5.04 b$ & $0.57 b$ & 11.3 & $53.39 b$ & $6.22 b$ \\
\hline & 2 & $5.82 \mathrm{a}$ & $1.00 \mathrm{a}$ & 17.2 & $64.22 \mathrm{a}$ & $11.27 a$ \\
\hline
\end{tabular}

aFor each location and observation variable, sub-samples with the same letter are not significantly different based on T-tests at $\mathrm{u}=0.05$ level. Sub-sample 1 : sub-population with 2:1 ratio between homozygous KK normal and heterozygous Kk kopyor coconut trees. Sub-sample 2: sub-population with the 1:1 ratio between homozygous KK normal and heterozygous Kk kopyor coconut trees 
Before cutting down (thinning) of homozygous KK normal trees (KK: Kk ratio $=1: 2.95)$, the average number of kopyor nut yield is 15.36 (ranging from 10.24 to 19.10) nuts per tree per year and the average percentage of

Table 3: Frequency of homozygous KK normal male parent pollen contributions to heterozygous Kk kopyor female parent causing kopyor nut yield reduction because of xenia

\begin{tabular}{lccc}
\hline $\begin{array}{l}\text { Female parent } \\
\text { identity }\end{array}$ & $\begin{array}{c}\text { No. } \\
\text { Harvested } \\
\text { nuts per } \\
\text { bunch }\end{array}$ & $\begin{array}{c}\text { Number identified genotype } \\
\text { of pollen donors }\end{array}$ \\
\cline { 3 - 4 } & 3 & $\begin{array}{c}\text { Heterozygous } \\
\text { Kk }\end{array}$ & $\begin{array}{c}\text { Homozygous } \\
\text { KK }\end{array}$ \\
\hline $\begin{array}{l}\text { Heterozygous } \\
\text { Kk\#149 }\end{array}$ & 3 & 2 & 1 \\
$\begin{array}{l}\text { Heterozygous } \\
\text { Kk\#156 }\end{array}$ & 3 & 2 & 1 \\
$\begin{array}{l}\text { Heterozygous } \\
\text { Kk\#163 }\end{array}$ & 3 & 1 & 2 \\
\hline
\end{tabular}

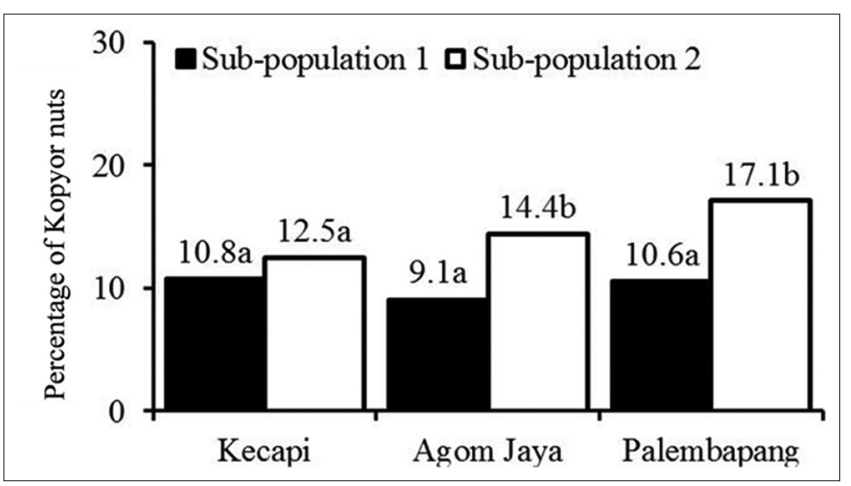

Fig 5. Differences in percentage of Kopyor nut per bunch between two sub-samples of Kalianda Tall heterozygous Kk Kopyor coconut at three locations (Kecapi, Agom Jaya, and Palembapang). Data are the average of three years of observation. Sub-sample 1: the ratio between homozygous KK normal and heterozygous Kk Kopyor coconuts is 2:1. Sub-sample 2: the ratio between homozygous KK normal and heterozygous Kk Kopyor coconut is 1:1. For each location, numbers followed by the same letter indicated not significantly different based on T-test at $\alpha=0.05$ level.

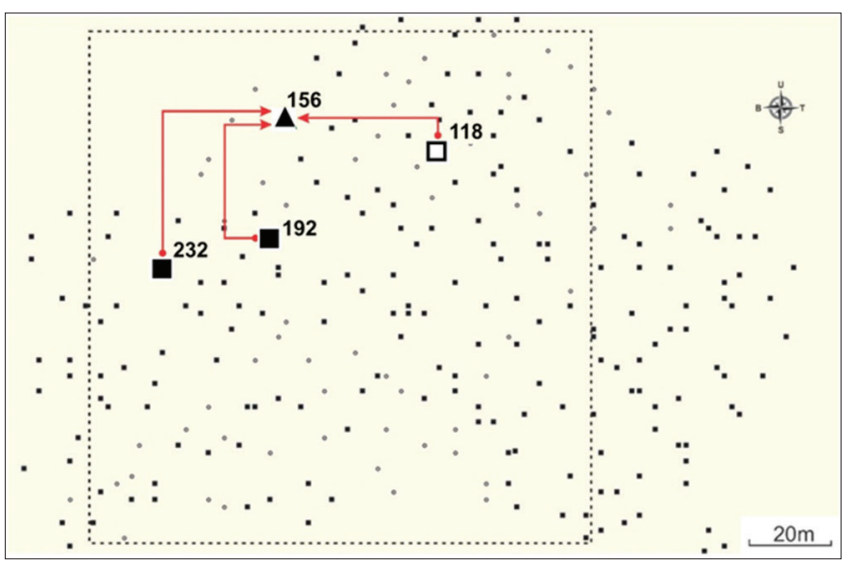

Fig 6. Three assigned male parents (no. 118, 192, and 232), inferred from parentage analysis, are donating pollen to female parent no. 156. Symbols represent position of: ( $\mathbf{\Delta})$ Tall kopyor female parent no. 156, (匹) Heterozygous Kk Kopyor male parents (no. 192 and 232), and (口) Homozygous KK normal male parent (no. 118). kopyor nuts per bunch was $28.5 \%$ (ranging from $24.2 \%$ to $31.8 \%$ ). After removal of the homozygous KK normal coconuts $(\mathrm{KK}: \mathrm{Kk}$ ratio $=1: 6.21)$, the average number of kopyor nut yield is higher than before removal. The average kopyor nut yield after removal of homozygous KK normal coconut is 17.46 (ranging from: 14.74 to 21.04) nuts per tree per year whereas the average percentage of kopyor nut per bunch was $35.2 \%$ (ranging from $34.5 \%$ to $36.5 \%$ ) (Fig. 8). The example of endosperm phenotype segregation (normal versus kopyor endosperm) from a single bunch of Pati Dwarf heterozygous Kk kopyor coconut is presented in Fig. 1e. Thus, negative effects of the homozygous KK normal coconut trees on kopyor nut yield are also observed in Pati Dwarf heterozygous $\mathrm{Kk}$ kopyor coconuts. When the homozygous KK normal coconuts were cut down from the mix coconut plantation, the kopyor nut yield increased. Removal of homozygous KK normal coconuts reduces probability of normal pollen carrying the $\mathrm{K}$ allele to pollinate the female flower of the heterozygous Kk Kopyor coconut, which in turn increases possibility of getting kopyor nuts from the female parents.

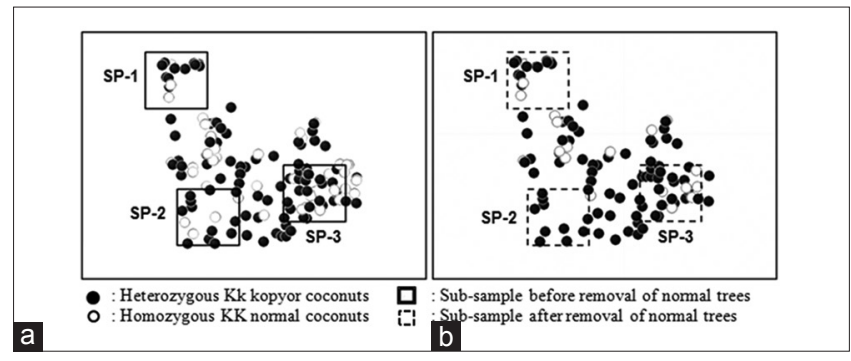

Fig 7. Maps of the coconut provenances at Tayu, Pati, Central Java, Indonesia. Small plots indicate the evaluated sub-population samples (SP-1, SP-2, and SP-3). (a) Coconut provenances before - and (b) after the cutting down (thinning) of homozygous KK normal coconuts as the source of pollen contaminants.

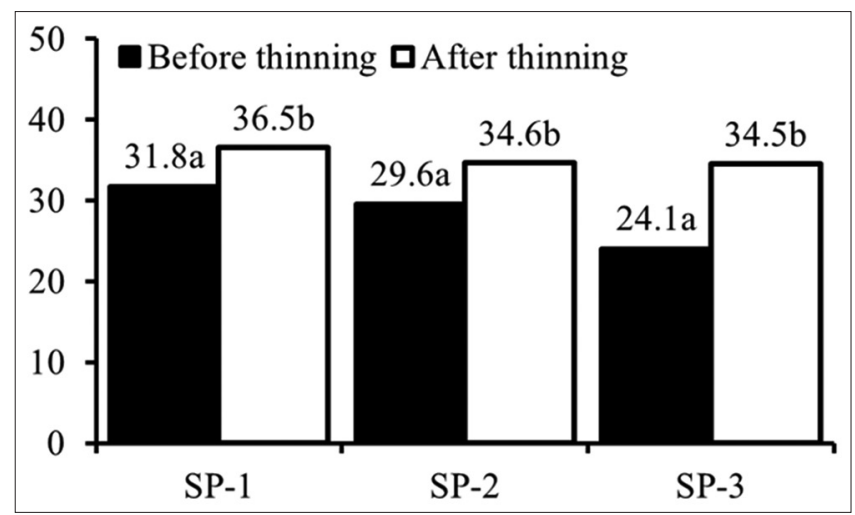

Fig 8. Differences in percentage of Kopyor nut per bunch in Pati Dwarf kopyor coconut at Tayu, Pati, Central Java before and after the cutting down (thinning) of homozygous KK normal coconut trees as the source of pollen contaminant in the location. SP-1, SP-2, and SP-3: sub-population sample 1,2 and 3, respectively. For each SP, numbers followed by the same letter indicated not significantly different based on T-test at $\alpha=0.05$ level. 
Pollination by pollen carrying the $\mathrm{K}$ allele abolishes kopyor nut formation (Table 1).

Three Pati Dwarf heterozygous Kk kopyor coconuts were officially released as local kopyor coconut varieties in 2010. The reported potential kopyor nut yields of these varieties were 25-39\% (Maskromo et al., 2013). Higher kopyor nut yield have also been reported in other studies (Novarianto and Lolong, 2012). In the Novarianto and Lolong (2012) study, open pollination among mix plantation of Pati Dwarf coconuts yielded only $16 \%$ of Kopyor nuts per bunch. Hand pollination of Pati Dwarf heterozygous Kk Kopyor coconut using self pollen yielded 30\% kopyor nuts per bunch. On the other hand, natural self pollination from isolated bunches with self-pollens generated Kopyor nuts up to $46 \%$ per bunch (Novarianto and Lolong, 2012). Cutting down $50 \%$ of the existing homozygous KK normal coconut provenances among Pati Dwarf heterozygous Kk Kopyor population would result in increased kopyor nut yield. This increased in Kopyor nut yield may have been associated with the decrease of xenia effect due to less number of homozygous KK normal coconuts. It should be noted that kopyor nut yield may also be affected by genetics and other environmental factors. Such factors were not included in this study.

\section{Xenia to Increase Kopyor Nut Yield in coconuts}

Xenia because of the presence of homozygous KK normal coconut provenances among heterozygous $\mathrm{Kk}$ Kopyor reduces kopyor nut yield. However, if homozygous KK normal is replaced with homozygous kk Kopyor coconuts in the field, negative xenia effects on kopyor nut yield could probably be reversed. Mix coconut plantation consisting of heterozygous $\mathrm{Kk}$ and homozygous kk kopyor coconut provenances results in increased kopyor nut yield because the homozygous kk kopyor coconut could become pollen contributors donating the $\mathrm{k}$ allele. If the $\mathrm{k}$ allele carrying pollen fertilize female flowers of the heterozygous $\mathrm{Kk}$ kopyor, it would yield 50\% kopyor and 50\% normal nuts (Table 1). Currently, the homozygous kk kopyor coconut seedlings have been developed through zygotic embryo rescue (Sukendah et al., 2006; Mashud, 2013; Sudarsono et al., 2015). Zygotic embryos with a homozygous kk genotype are isolated from kopyor nuts and germinated under in vitro conditions (Sukendah et al., 2008; Mashud, 2013; Sudarsono et al., 2015). Once germinated, the resulting homozygous kk seedlings could be planted in the field (Sukendah et al., 2008) and under isolated environment it could yield 100\% Kopyor nuts per bunch (Novarianto et al., 2014). Although available, the price of homozygous $\mathrm{kk}$ kopyor coconut seedlings is either US $\$ 50,00$ for Tall Kopyor or US $\$ 100,00$ for Dwarf Kopyor coconuts (Maskromo et al., 2015), which is too expensive to farmers.
We are proposing to plant a few homozygous $\mathrm{kk}$ kopyor among either Tall or Dwarf heterozygous Kk Kopyor coconuts. The homozygous kk kopyor could become pollen donors to the heterozygous Kk kopyor coconuts and increase the expected kopyor yield from the heterozygous $\mathrm{Kk}$ kopyor coconuts up to $50 \%$. The other $50 \%$ of the yield are normal nuts having heterozygous Kk zygotic embryos. Therefore, planting such kopyor homozygous kk coconut provenances among the heterozygous $\mathrm{Kk}$ kopyor would probably result in a positive effect of xenia because of the $k$ allele contribution from pollen donors increases the expected kopyor nut yield from $25 \%$ to $50 \%$. This approach was more reasonable to kopyor farmers because to plant 3 to 5 kopyor homozygous kk coconut seedlings as pollen donors among the 30-50 existing kopyor heterozygous $\mathrm{Kk}$ provenances would not require a large amount of investment. Such approach has been the subject of evaluation in the Hi-LINK Kopyor Coconut Project (Sudarsono et al., 2013).

\section{CONCLUSIONS}

Xenia in kopyor coconut mutants occurs because of the presence of either the Tall or Dwarf homozygous KK normal among the heterozygous Kk kopyor coconuts. Such xenia negatively affect kopyor nut yield of both Kalianda Tall and Pati Dwarf heterozygous Kk Kopyor coconuts. The smaller the ratio of $\mathrm{KK}: \mathrm{Kk}$ in both Kalianda Tall or Pati Dwarf Kopyor coconuts, the lower the negative effects of xenia on kopyor nut yield. It was suggested to plant homozygous kk kopyor of the respective varieties as pollen donor among heterozygous Kk kopyor coconut provenances as a counter strategy to increase kopyor nut production at the farmer's level.

\section{ACKNOWLEDGEMENT}

This research was partially supported by DGHE, MoEC, Republic of Indonesia through "HI-LINK Kopyor Coconut Project - 2012-2014" entitled "Increasing Kopyor Fruit Yield with the Help of Honey Bee Pollinators and Production of Kopyor true-to-type Seedlings through Control Pollination" coordinated by Sudarsono. This research is used by Ismail Maskromo to write part of his $\mathrm{PhD}$ dissertation. The authors acknowledge the assistance of Disbun Lampung Selatan and Dishutbun Pati and also appreciate for the help of Siswanto and Agus Susetyo Purwono for field activities.

\section{Authors contributions}

Ismail Maskromo has participated in the field experiments and data collection about the xenia effects in Kopyor coconut and contributed to the writing of the manuscript. 
Siti Halimah Larekeng has participated in the laboratory experiment and data collection about the molecular analysis of xenia in Kopyor coconut.

Hengky Novarianto has participated in the field experiments and data collection about the xenia effects in Kopyor coconut.

Sudarsono Sudarsono has been the project principal investigator and the corresponding author - designed the research plan, organized the study, participated in field and laboratory data collection, conducted the data analysis and contributed to the writing of the manuscript.

\section{REFERENCES}

Disbun-Lampung-Selatan. 2011. Laporan Tahunan (Annual Report) Dinas Perkebunan Kabupaten Lampung Selatan, Dinas Perkebunan, Lampung Selatan, Lampung.

Dishutbun-Pati. D. 2004. Selayang Pandang Komoditi Kelapa Kopyor di Kabupaten Pati. Dinas Kehutanan dan Perkebunan Kabupaten Pati, Jawa Tengah.

Faraq, K. M., A. S. Elsabagh and H. A. Elashry. 2012. Fruit characteristics of "Zaghloul" date palm in relation to metaxenic influence of used pollinator. Am. Euras. J. Agric. Environ. Sci. 12(7): 842-855.

Larekeng, S. H., I. Maskromo, A. Purwito, N. A. Matjik dan S. Sudarsono. 2015. Pollen dispersal and pollination pattern studies in pati kopyor coconut using molecular markers. Int. J. Coconut Res. Dev. (CORD). 31(1): 46-60.

Mashud, N. 2013. Efek zat pengatur tumbuh BAP terhadap pertumbuhan planlet kelapa Genjah kopyor yang dibelah. Bull. Palma. 14(2): 82-87.

Maskromo, I., N. Mashud, H. Novarianto. 2007. Potensi pengembangan kelapa kopyor di Indonesia. Warta Penelitian dan Pengembangan Pertanian. 13(1): 4-6.

Maskromo, I., H. Novarianto, D. Sukma, and Sudarsono. 2011. Potensi hasil plasma nutfah kelapa Kopyor asal Kalianda, Pati, Sumenep dan Jember. In: Prosiding Seminar Nasional Pemanfaatan Sumberdaya Genetik (SDG) Lokal Mendukung Industri Perbenihan Nasional. Penerbit Universitas Padjajaran, Bandung, HIm, 499-506.

Maskromo, I., H. Novarianto, Sukendah, D. Sukma and Sudarsono. 2013. Productivity of three Dwarf kopyor coconut varieties from Pati, Central Java, Indonesia. Int. J. Coconut Res. Dev. (CORD) 29(2): 19-28.

Maskromo, I., H. Novarianto, Sukendah, D. Sukma dan S. Sudarsono. 2014. Keragaman komponen buah dan kualitas endosperma kelapa dalam kopyor Kalianda dan kelapa Genjah kopyor Pati. Bul. Palma. 15(2): 102-109.

Maskromo, I., E. T. Tenda, M. A. Tulalo, H. Novarianto, D. Sukma, Sukendah and Sudarsono. 2015. Keragaman fenotipe dan genetik tiga varietas kelapa genjah Kopyor asal Pati, Jawa Tengah. J. Littri. 21(1): 1-8.

Marshal, T. C., J. Slate, L. E. B. Krilek and J. M. Pemberton. 1998. Statistical confidence for likely-hood based paternity inference in nature populations. Mol Ecol. 7: 639-655.

Novarianto $H$. and A. A. Lolong. 2012. Peningkatan persentase buah kelapa kopyor melalui penyerbukan sendiri. Bul. Palma. 13(1): 7-16.

Novarianto, H., I. Maskromo, D. Dinarti and Sudarsono. 2014. Production techology for coconut seednuts and seedlings in Indonesia. Int. J. Coconut Res. Dev. (CORD) 30(2): 31-40.

Olfati, J. A., Z. Sheykhtaher, R. Qamgosar, A. K. Sabet, G. H. Peyvast, H. Samizadeh and B. Rabiee. 2010. Xenia and metaxenia on cucumber fruit and seed characteristics. Int. J. Veg. Sci. 16: 243-252.

Satyabalan, K. 1995. Xenia effect and hybrid vigor in coconuts. Int. J. Coconut Res. Dev. (CORD). 11(1): 41-47.

Stewart-Cox, J. A., N. F. Britton and M. Mogie. 2004. Endosperm triploidy has a selective advantage during ongoing parental conflict by imprinting. Proc. Royal Society B. Biol. Sci. 271.1549: 1737-1743.

Sudarsono, H. Novarianto, M. L. A. Hossang, D. Dinarti, Yuliasti, D. Sukma, and I. Maskromo. 2013. Produksi bibit kelapa kopyor true to type dengan persilangan terkontrol dan peningkatan produksi buah kelapa kopyor dengan polinator lebah madu. Laporan Tahunan (Annual Report) - Program Hi-Link Kelapa Kopyor. Institut Pertanian Bogor, Bogor, Indonesia.

Sudarsono, S., H. Novarianto, M. L. A. Hosang, D. Dinarti, D. Yuliasti and S. D. I. Maskromo. 2015. Pendekatan genomik dan molekuler untuk pengembangan kultivar unggul kelapa eksotik asal Indonesia, penyediaan bibit dan oengendalian hamanya. Laporan Tahunan (Annual Report) - Program KKP3N Kelapa Kopyor. Institut Pertanian Bogor, Bogor, Indonesia.

Sukendah, I.N. Djajanegara and Makhziah. 2006. Protokol kultur embryo sigotik kelapa kopyor. J. Sains Teknol. Indones. 8(1): 15-20.

Sukendah, Sudarsono, Witjaksono dan N. Khumaida. 2008. Perbaikan teknik kultur embryo (Cocos nucifera L.) asal Sumenep Jawa Timur melalui penambahan bahan aditif dan pengujian periode sub-kultur. Bul. Agron. 36(1): 16-23.

Sukendah, S., H. Volkaert and S. Sudarsono. 2009. Isolation and analysis of DNA fragment of genes related to 'Kopyor' trait in coconut plant. Indones. J. Biotechnol. 14(2): 1169-1178.

Viorica, U. and B. Dorina. 2013. Data on pollen-mediated gene flow from genetically modified maize to conventional maize under simultaneous sowing conditions. J. Hortic. Forest. Biotechnol. 17(4): 90-94. 